\title{
Chemical Composition, Proapoptotic and Antiosteoporosis Activities of the Essential Oil from the Aerial Part of Alpinia officinarum Hance
}

\author{
Yang Wang ${ }^{1,2,3^{*}}$, Ji Chen ${ }^{4 *}$, Keda Zhang ${ }^{2}$, Weigang $\mathrm{Wu}^{2}$, Lanlan Ge ${ }^{2,5}$, Haoqiang Wan ${ }^{2}$, Jiemei Li², \\ Jun Tian ${ }^{1,6 \#, ~ X i a o b i n ~ Z e n g ~} 1,2,7 \#$
}

\begin{abstract}
${ }^{1}$ Key Lab for New Drug Research of TCM and Shenzhen Branch, State R\&D Centre for Viro-Biotech, Research Institute of Tsinghua University in Shenzhen, Shenzhen, China

${ }^{2}$ Center Lab of Longhua Branch, Shenzhen People's Hospital, Second Clinical Medical College of Jinan University, Shenzhen, China

${ }^{3}$ Shenzhen Hanyu Pharmaceutical Co., Ltd., Shenzhen, China

${ }^{4}$ Department of Orthopedics, Shenzhen People's Hospital, 2nd Clinical Medical College of Jinan University, Shenzhen, China ${ }^{5}$ Department of Infectious Disease, Shenzhen People's Hospital, 2nd Clinical Medical College of Jinan University, Shenzhen, China

${ }^{6}$ College of Life Science, Jiangsu Normal University, Xuzhou, China

${ }^{7}$ Guangdong Key Laboratory for Research and Development of Natural Drugs, Guangdong Medical University, Zhanjiang, China Email: "zengxiaobin1983@163.com, "tj-085@163.com
\end{abstract}

How to cite this paper: Wang, Y., Chen, J., Zhang, K.D., Wu, W.G., Ge, L.L., Wan, H.Q., Li, J.M., Tian, J. and Zeng, X.B. (2018) Chemical Composition, Proapoptotic and Antiosteoporosis Activities of the Essential Oil from the Aerial Part of Alpinia officinarum Hance. Chinese Medicine, 9, 144-164. https://doi.org/10.4236/cm.2018.93009

Received: July 6, 2018

Accepted: August 6, 2018

Published: August 9, 2018

Copyright $\odot 2018$ by authors and Scientific Research Publishing Inc. This work is licensed under the Creative Commons Attribution International License (CC BY 4.0).

http://creativecommons.org/licenses/by/4.0/ (c) (i)

Open Access

\begin{abstract}
Background: Alpinia officinarum Hance is valued as an edible medicinal plant. The rhizome is widely reported to have anticancer activity whereas litthe information is available on the aerial part. This study investigates chemical composition, proapoptotic and anti-osteoporosis activities of essential oil from aerial parts of $A$. officinarum (APEO). Methods: In this study, APEO was extracted by hydrodistillation and analyzed using GC-MS. The inhibitive activity of $0-2.5 \mu \mathrm{L} / \mathrm{mL}$. APEO was investigated using MTT assay, while in vivo effect was evaluated in nude mice. The cell cycle, apoptosis, $\Delta \Psi \mathrm{m}$ and expression of proteins analyses influenced by $0-0.313 \mu \mathrm{L} / \mathrm{mL}$ APEO were detected by PI, Annexin V/PI, JC-1, and Western blot, respectively. Alkaline phosphatase activity and mineralized nodules formation of rat osteoblasts with $0-0.156 \mu \mathrm{L} / \mathrm{mL}$ APEO were assayed using colorimetric method and alizarin red staining, respectively. Results: Total 45 constituents were identified accounting for $91.1 \%$ of APEO (sesquiterpene hydrocarbons for 44.4\%). APEO significantly inhibited cancer cells growth in a dose-dependent manner. APEO
\end{abstract}


also inhibited cancer growth in vivo. The percentage of $S$ phase cells is up to $64.846 \%$ with $0.313 \mu \mathrm{L} / \mathrm{mL}$ APEO. The proportion of total apoptotic cells significantly increased to $79.6 \%$ at $0.313 \mu \mathrm{L} / \mathrm{mL}$ concentration. APEO treated cells accompanied with $\mathrm{Bcl}-2$ and $\Delta \Psi \mathrm{m}$ decrease, and caspase-3 and p53 upregulation. Furthermore, addition of APEO in rat osteoblasts led to a dose-dependent increase in ALP activity and formation of mineralized bone nodules. Conclusions: Our data suggest that APEO could be developed as an agent against human lung cancer and osteoporosis, especially cancer-induced bone loss.

\section{Keywords}

Alpinia officinarum Hance, Essential Oil, Cancer, Apoptosis, Anti-Osteoporosis

\section{Background}

Essential oils have been widely used as fragrances and flavoured agents in foods and drugs [1]. Recently, the pharmaceutical industry has expressed more interest in essential oils because of their multiple functions, especially anticancer activities [2]. Hence, it is important to develop a better understanding of the biological action of essential oils for new applications in human health.

Alpinia officinarum Hance has been frequently used as spice and medicine throughout Asian countries for centuries [3]. The rhizome of $A$. officinarum, known as galangal, can be used to warm spleen and stomach for dispelling cold and regulate the flow of Qi to alleviate pain in traditional Chinese medicine, as detailed in the entry "Gaoliangjiang" of Chinese pharmacopeia (volume 1, 2015). Modern studies have pointed out that galangal has other interesting bioactivities, such as anticancer, antioxidant and antimicrobial properties [4] [5]. For instance, the $80 \%$ aqueous acetone extract from galangal inhibited melanogenesis in theophylline-stimulated murine B16 melanoma 4A5 cells with four diarylheptanoids and two flavanol being the active constituents for the inhibition [4]. Many researchers have largely reported the essential oil from galangal, which comprises a very diverse set of compounds that impart many medicinal effects, like 1, 8-cineole, $\alpha$-pinene, $\beta$-pinene, $\alpha$-terpineol, camphene, limonene, p-cymene, camphor, trans- $\alpha$-bergamotene, $\beta$-elemene, terpinen-4-ol, and $\delta$-cadinene [6]. 1,8-Cineole, accounting for $65.6 \%$ of the essential oil [7], has mucolytic, bronchodilating and anti-inflammatory properties [8] as well as anticancer and antibacterial activities [9] [10]. Another major constituent, $\delta$-cadinene, can used to kill acarids [11] and mosquitoes [12] and to inhibit the growth of ovarian cancer cells [13]. Unlike the rhizomes, the aerial part of $A$. officinarum has been little studied up to now. Zhang et al. isolated five flavonoids including galangin, pinocembrin, 3-O-methylgalangin, pinobaksin and kaempferide from an ethanol extract of the aerial part [14]. Zhang et al. further identified other eight flavonoids (i.e., chrysin, tectochrysin, apigenin, acacetin, kaempferol, quercetin, isorhamnetin and rutin) and four diarylheptanoids (i.e., yakuchinone A, oxyphyllacinol, hex- 
ahydrocurcumin, and hannokinol) from the methanol extract of $A$. officinarum leaves by liquid chromatography-mass spectrometry [15]. The utilisation of the aerial part of $A$. officinarum is still low, and annually a large amount of the aerial part of $A$. officinarum is discarded as a waste from $A$. officinarum production.

Lung cancer is one of the most common cancers worldwide and its occurrence is increasing annually. Lung cancer is the most common cause of cancer-related death in men and women, causing 1.38 million deaths annually as of 2008 [16]. Apoptosis is a form of programmed cell death that is necessary for the destruction of cells considered a threat, such as cells infected with viruses, cells with DNA damage, and cancerous cells. During apoptosis, cellular contents are not released and inflammation does not occur. Impaired regulation of apoptosis leads to a variety of diseases [17]. Cells undergoing apoptosis show characteristic morphological and biochemical features including chromatin aggregation, nuclear and cytoplasmic condensation, and the partition of cytoplasm and the nucleus into apoptotic bodies containing ribosomes, morphologically intact mitochondria and nuclear material [18]. In vivo, these apoptotic bodies are rapidly recognized and phagocytized by either macrophages or adjacent epithelial cells. Due to this efficient mechanism for the removal of apoptotic cells in vivo, no inflammatory response occurs. In vitro, the apoptotic bodies and the remaining cell fragments ultimately swell and finally lyse. This terminal phase of in vitro cell death has been termed "secondary necrosis" [19]. Apoptosis inducers can prevent tumor formation, and side effects are rare.

Also, patients with cancer are at risk for adverse skeletal effects, including metastatic bone disease and treatment-related bone loss [20]. Bone is a commonly affected organ in cancer, and although the incidence of metastatic bone disease is not well defined, it is estimated that bone involvement occurs in around half of patients who die from cancer in the United States annually [21]. Cancer-induced bone disease can result from two factors: therapies administered to treat the primary disease that have side effects of bone loss and fractures or the primary disease itself, either due to circulating bone resorbing substances or metastatic bone disease, which commonly occurs with breast, lung and prostate cancer [21]. Tumor-induced skeletal effects include pathological fractures, spinal cord compression, and surgery and radiotherapy to bone and can also include hypercalcaemia of malignancy, skeletal complications from cancer include pain and other symptoms.

In order to better explore the potential value of the aerial part, the present study focuses on the chemical composition, proapoptotic, and anti-osteoporosis activities of its essential oil (APEO), whose structural and bioactive diversity may be expected from the common characteristics of essential oils.

\section{Methods}

\subsection{Plant Materials}

The aerial parts of $A$. officinarum Hance were harvested in Xuwen County (east 
longitude: $109^{\circ} 52^{\prime}-110^{\circ} 35^{\prime}$; north latitude: $20^{\circ} 13^{\prime}-20^{\circ} 43^{\prime}$ ), Guangdong, China in September 2013. No permits were required for the described studies, and the field studies did not involve any endangered or protected species. The plant materials were initially identified by its morphological features and were finally confirmed by Dr. Xiaobin Zeng, one of the coauthors. The voucher specimens (No. 130915) have been deposited at the herbarium of Guangdong Key Laboratory for Research and Development of Natural Drugs in Guangdong Medical University, China.

\subsection{APEO Extraction}

The aerial parts of $A$. officinarum were air-dried at room temperature for one week. The dried plant material was pulverized with distilled water and submitted to hydro-distillation in a Clevenger-type apparatus for $3 \mathrm{~h}$. The resulting oil layer was separated and dried with anhydrous sodium sulfate. The dried oil was then stored at $-4^{\circ} \mathrm{C}$ until use. The yield of oil was calculated as a percentage of volume per weight $(\% \mathrm{v} / \mathrm{w})$ of the dried plant material.

\subsection{Gas Chromatography-Mass Spectrometry (GC-MS) and Gas Chromatography-Flame Ionization Detection (GC-FID) Analysis}

The chemical composition of APEO was analyzed using GC-MS (Thermal Trace GC Ultra coupled with a Polaris Q ion-trap mass spectrometer; Shimadzu, Kyoto, Japan) with a HP-Innowax capillary column $(30 \mathrm{~mm} \times 0.25 \mathrm{~mm} \times 0.25 \mu \mathrm{m}$; Agilent Technologies, Forster, CA, USA). APEO was diluted ( $1 \mu \mathrm{L}, 1: 100, \mathrm{v} / \mathrm{v}$, in cyclohexane) and then manually injected in the spilt mode (split ratio of 1/50). Helium was used as the carrier gas at a flow rate of $1 \mathrm{~mL} / \mathrm{min}$. The column temperature was programmed from $50^{\circ} \mathrm{C}$ to $280^{\circ} \mathrm{C}$ at $10^{\circ} \mathrm{C} / \mathrm{min}$. Injector and detector temperatures were maintained at $280^{\circ} \mathrm{C}$. The mass spectrometer was operated in the electron-impact (EI) mode by the energy of $70 \mathrm{eV}$. Mass spectra were recorded in the 30 - $450 \mathrm{amu}$ range. Retention indices were determined for all volatile constituents using a homologous series of $\mathrm{C}_{9}-\mathrm{C}_{19} \mathrm{n}$-alkanes. The relative concentration of each compound was quantified by peak area normalization using GC-FID. The components were identified by matching their mass spectra with those in the NIST08s GC/MS library (National Institute of Standards and Technology) and in the literature [22], or by co-injection of available reference compounds. All samples were analyzed in triplicate.

\subsection{Cancer Cell Culture}

Human cancer cell lines (A549, NCI-H460, NCI-H23, MCF-7, HL-60 and Hela) were obtained from American Type Culture Collection. These cells were grown and cultured in an RPMI 1640 medium containing 10\% fetal bovine serum (FBS) at $37^{\circ} \mathrm{C}$ in humidified air containing $5 \% \mathrm{CO}_{2}$. APEO was dissolved in glycerin at different concentrations $(\leq 0.5 \%)$. In all experiments, glycerin alone was used as the control. 


\subsection{Cell Proliferation Assay}

Cancer cells were seeded in a 96-well plate at a density of $5 \times 10^{3}$ cells per well. The cells were allowed to adhere for $24 \mathrm{~h}$ under standard conditions, and then exposed to the varying concentrations of APEO and cisplatin $24 \mathrm{~h}$ after the seeding. At $48 \mathrm{~h}$ post-treatment, $20 \mu \mathrm{L}$ 3-(4,5-dimethylthiazol-2-yl)-2,5-diphenyltetrazolium bromide (MTT) solution in PBS $(20 \mathrm{mg} / \mathrm{mL})$ are added to each well and incubated for $4 \mathrm{~h}$, and the medium was then replaced by $200 \mu \mathrm{L}$ of DMSO followed by incubation at room temperature for $4 \mathrm{~h}$. The absorbance at $570 \mathrm{~nm}$ was recorded using a microplate reader. The cell viability was calculated relative to the absorbance of the control. The same procedure was carried out for rat osteoblasts below.

\subsection{Anti-Lung Tumor Assay}

All protocols involving animal experiments were approved by the ethics committee of Shenzhen People's Hospital (Guangdong, China), and conducted in uniformity with national guidelines of the care and use of laboratory animals. Six-week-old female nude mice (Balb/c-nu/nu) were purchased from Guangdong Medical Laboratory Animal Center. The mice were subcutaneously injected in the back with $2 \times 10^{6}$ exponential proliferating A549 cells suspended in PBS. The mice were randomly allocated to 5 groups with 10 animals per group: the control group, APEO groups $(1,5,10 \mathrm{~mL} / \mathrm{kg})$ and the cisplatin group $(10 \mathrm{mg} / \mathrm{kg})$. APEO was dissolved in glycerin at a concentration of $0.5 \mathrm{~mL} / \mathrm{mL}$, and cisplatin in normal saline at $5.0 \mathrm{mg} / \mathrm{mL}$. When the tumor nodules had reached a volume of $100 \mathrm{~mm}^{3}$ approximately 15 days post injection, APEO groups were gavaged with APEO at 1,5 and $10 \mathrm{~mL} / \mathrm{kg}$, respectively, and the cisplatin group was administered 10 $\mathrm{mg} / \mathrm{kg}$ cisplatin via intraperitonel injection. The treatments were performed every other day. Mice were euthanized by $\mathrm{CO}_{2}$ inhalation 20 days after the first treatment, and the tumor tissues were harvested. The length and width of the tumors were measured using a Vernier caliper and the tumor volume was calculated as (length $\times$ width $\left.^{2}\right) / 2$.

\subsection{Cell Cycle Analysis}

A549 cells were plated at a density of $1 \times 10^{5}$ cells/well in a six-well plate. After 24 $\mathrm{h}$ incubation for adherence, the cells were treated with APEO $(0-1.25 \mu \mathrm{L} / \mathrm{mL})$ for $48 \mathrm{~h}$. Then the cells were fixed overnight with $95 \%$ ethanol at $4^{\circ} \mathrm{C}$ for $24 \mathrm{~h}$ and stained with PI solution $(100 \mu \mathrm{g} / \mathrm{mL})$. Cell-cycle distribution analysis was performed using a flow cytometer (Beckman-Coulter, Indianapolis, IN, USA).

\subsection{Apoptosis Analysis}

Annexin V-FITC/PI double staining of the cells was determined using an Annexin V-FITC kit (BD Pharmingen, San Diego, USA). After the same treatments as above, the cells were harvested with trypsin, washed twice with cold PBS, and then resuspended in $500 \mu \mathrm{L}$ of Annexin V binding buffer. The suspended cells 
were mixed with $5 \mu \mathrm{L}$ of Annexin V-FITC solution and $5 \mu \mathrm{L}$ of PI solution, incubated for $15 \mathrm{~min}$ at room temperature in the dark, and analyzed by a flow cytometer (Beckman-Coulter, Indianapolis, IN, USA). Annexin V-FITC and PI emissions were detected in the FL 1 and FL 2 channels, and approximately 10,000 counts were recorded per sample. The percentages of normal (Annexin $\mathrm{V}^{-} / \mathrm{PI}^{-}$), early apoptotic (Annexin $\mathrm{V}^{+} / \mathrm{PI}^{-}$), late apoptotic (Annexin $\mathrm{V}^{+} / \mathrm{PI}^{+}$), and necrotic cells (Annexin $\mathrm{V}^{-} / \mathrm{PI}^{+}$) were calculated by FlowJo software (TreeStar, Ashland, OR, USA).

\subsection{Apoptosis Analysis by DAPI Staining}

Following $48 \mathrm{~h}$ of treatments with either glycerin alone or different doses of APEO, the cells were fixed with pre-chilled methanol for $2 \mathrm{~min}$, and then stained with $0.5 \mu \mathrm{g} / \mathrm{mL}$ of 4,6-diamidino-2-phenylindole (DAPI) for $10 \mathrm{~min}$. Nuclei were examined and photographed using fluorescence microscopy.

\subsection{Mitochondrial Membrane Potential ( $\left.\Delta \Psi_{\mathrm{m}}\right)$ Assay}

The membrane-permeant JC-1 dye is widely used in apoptosis studies to monitor mitochondrial health. JC-1 dye exhibits potential-dependent accumulation in mitochondria, accompanied with fluorescence emission shift from green to red. Consequently, the mitochondrial membrane potential is indicated by the red/green fluorescence intensity ratio. After treatment with APEO, the cells were incubated at $37^{\circ} \mathrm{C}$ with $5 \mathrm{mg} / \mathrm{L} \mathrm{JC}-1$ (Beyotime Biotech, Nantong, China) for $1 \mathrm{~h}$, and then rinsed twice with PBS and placed in a fresh medium without FBS. The cells were analyzed on a flow cytometer (Beckman-Coulter, Indianapolis, IN, USA) using $488 \mathrm{~nm}$ excitation with $530 \mathrm{~nm}$ and $590 \mathrm{~nm}$ bandpass emission filters.

\subsection{Western Blot Analysis}

A549 cells were seeded at a density of $2 \times 10^{6}$ cells in a $25 \mathrm{~cm}^{2}$ flask and allowed to adhere for $24 \mathrm{~h}$. The cells were then treated with various doses of APEO (0, $0.078,0.156$ and $0.313 \mu \mathrm{L} / \mathrm{mL}$ ) for $12 \mathrm{~h}$. Cell lysates were prepared using cold cell lysis buffer on ice, and then clarified by centrifugation. The supernatants were collected and stored at $-70^{\circ} \mathrm{C}$ until use. Protein concentrations were measured using the Bradford method [23]. Equal amounts of protein were loaded and separated using $10 \%$ polyacrylamide gel electrophoresis and transferred onto a polyvinylidene fluoride membrane. The membrane was blocked with $5 \%$ fat-free milk at room temperature for $1 \mathrm{~h}$ and incubated with the specific primary antibody (1:500) at $4^{\circ} \mathrm{C}$ overnight. Protein bands were detected with an enhanced chemiluminescence kit after incubating in secondary horseradish peroxidase-conjugated goat anti-rabbit IgG antibody (1:1000) at room temperature for $1 \mathrm{~h}$ and exposed to film for autoradiography. The band densities were quantified using ImageJ software (National Institutes of Health, Bethesda, Maryland, USA). 


\subsection{Isolation and Culture of Rat Osteoblasts}

Osteoblasts were enzymatically isolated from fetal Wistar rat calvaria using a slightly modified method of Declercq and her colleagues [24]. Briefly, skin and soft connective tissue were removed. The bone was cut into $1 \mathrm{~mm}^{2}$ square pieces and washed twice in PBS. The bone pieces were digested sequentially in a trypsin II-S (25 mg)-collagenase IA (70 mg) in $15 \mathrm{~mL}$ PBS solution at $37^{\circ} \mathrm{C}$ for 20 and $70 \mathrm{~min}$. Osteoblasts obtained from the two digestions were plated together in a T25 tissue culture dish at a concentration of $50,000 \mathrm{cells} / \mathrm{cm}^{2}$, and then cultured in DMEM supplemented with $10 \% \mathrm{FBS}$ at $37^{\circ} \mathrm{C}$ in a $5 \% \mathrm{CO}_{2}$ humidified atmosphere.

\subsection{Alkaline Phosphatase (ALP) Activity Assay}

Osteoblasts $\left(5 \times 10^{4}\right.$ cells per well) were added into a 24 -well plate and incubated for $24 \mathrm{~h}$. The cells were then treated with the culture medium containing APEO at concentrations of $0,0.039,0.078$ and $0.156 \mu \mathrm{L} / \mathrm{mL}$. At different time points after treatment, the cells were washed twice with $50 \mathrm{mM}$ PBS (pH 7.4) and kept overnight in a $0.1 \%$ Triton $\mathrm{X}-100$ lysis buffer at $-20^{\circ} \mathrm{C}$. The cells were thawed, and then incubated with $300 \mu \mathrm{L}$ of substrate buffer $(6.7 \mathrm{mmol} / \mathrm{L}$ disodium p-nitrophenylphosphate hexahydrate, $25 \mathrm{mmol} / \mathrm{L}$ diethanolamine, and $1.0 \mathrm{mmol} / \mathrm{L}$ $\mathrm{MgCl}_{2}$ ) at $37^{\circ} \mathrm{C}$ for $30 \mathrm{~min}$. The absorbance at $405 \mathrm{~nm}$ was recorded using a microplate reader.

\subsection{Determination and Quantification of Mineralized Bone Nodules}

Osteoblasts $\left(1 \times 10^{5}\right.$ cells per well) were seeded in 12 -well plates and incubated for $24 \mathrm{~h}$. An osteogenic medium (10 mM L-glycerophosphate, $50 \mu \mathrm{g} / \mathrm{mL}$ ascorbic acid) mixed with APEO was added to each well. After 20 days, the cells were fixed in $95 \%$ ethanol for $15 \mathrm{~min}$, stained with alizarin red $(40 \mathrm{mM}, \mathrm{pH} 7.2)$ for 10 min and then rinsed with PBS. Nodules were visualized using an inverted microscope, and their areas were quantified using Image-Pro Plus 6.0 software (Media Cybernetics, Silver Spring, MD, USA).

\subsection{Statistical Analysis}

All data were expressed as mean \pm standard deviation (SD) from three independent experiments in 3 - 5 replicates. Statistical difference was evaluated using analysis of variance and Dunnett's $t$-test, and $p<0.05$ was considered significant.

\section{Results}

\subsection{Chemical Composition of APEO}

APEO was obtained from the aerial parts of $A$. officinarum by hydrodistillation, with a yield of $1.03 \%(\mathrm{v} / \mathrm{w})$ on a dry weight basis. 45 main constituents, representing $91.1 \%$ of APEO, were identified by GC-MS and GC-FID (Table 1). 
Table 1. The main components of APEO and their contents.

\begin{tabular}{|c|c|c|c|}
\hline No. & $\mathrm{RI}^{\mathrm{a}}$ & Compounds & Percentage (\%) \\
\hline 1 & 1059 & Eucalyptol & 8.7 \\
\hline 2 & 1121 & Bicyclo[2.2.1] heptan-2-one & 2.9 \\
\hline 3 & 1137 & 3-Cyclohexen-1-ol, 4-methyl-1-(1-methylethyl) & 2.0 \\
\hline 4 & 1143 & 3-Cyclohexene-1-methanol, $\alpha, \alpha, 4$-trimethyl & 3.1 \\
\hline 5 & 1181 & Benzenepropanal & 3.4 \\
\hline 6 & 1204 & 3-Cyclohexene-1-carboxaldehyde,1,3,4-trimethyl & 0.8 \\
\hline 7 & 1228 & Benzylacetone & 3.3 \\
\hline 8 & 1277 & Fenchyl acetate & 3.4 \\
\hline 9 & 1277 & Bornyl acetate & 6.3 \\
\hline 10 & 1294 & Benzoic acid, 2-methylpropyl ester & 0.3 \\
\hline 11 & 1386 & 1H-Cycloprop[e]azulene, decahydro-1,1,7-trimethyl & 1.6 \\
\hline 12 & 1386 & 1H-Cycloprop[e]azulene, decahydrop-1,1,7-trimethyl & 3.8 \\
\hline 13 & 1396 & Naphthalene, 1,2-dihydro-1,1,6-trimethyl & 1.2 \\
\hline 14 & 1430 & Bicyclo[3.1.1]hept-2-ene,2,6-dimethyl-6-(4-methyl) & 5.2 \\
\hline 15 & 1435 & Naphthalene, 1,2,3,4,4a,5,6,8a-octahydro-7-methyl & 3.8 \\
\hline 16 & 1449 & 2-Butanone, 4-(2,6,6-trimethyl-1-cyclohexen-1-yl) & 0.2 \\
\hline 17 & 1454 & $\alpha$-Santalol & 1.2 \\
\hline 18 & 1458 & $\alpha$-Farnesene & 1.7 \\
\hline 19 & 1461 & Azulene, 1,2,3,3a,4,5,6,7-octahydro-1,4-dimethyl & 1.7 \\
\hline 20 & 1469 & Naphthalene, 1,2,3,5,6,8a-hexahydro-4,7-dimethyl & 1.7 \\
\hline 21 & 1469 & Naphthalene, decahydro-4a-methyl-1-methylene-7-methyl & 1.7 \\
\hline 22 & 1469 & $\begin{array}{l}\text { Naphthalene, } \\
\text { decahydro-4a-methyl-1-methylene-7-(1-methylethenyl) }\end{array}$ & 1.5 \\
\hline 23 & 1474 & Naphthalene, 1,2,3,5,6,7,8,8a-octahydro-1,8a-dimethyl & 1.2 \\
\hline 24 & 1494 & $\beta$-Caryophyllene & 5.2 \\
\hline 25 & 1507 & Caryophyllene oxide & 1.7 \\
\hline 26 & 1564 & 1,6,10-Dodecatrien-3-ol,3,7,11-trimethyl & 0.4 \\
\hline 27 & 1579 & $\alpha$-Humulene & 6.6 \\
\hline 28 & 1580 & 1-Naphthalenol, 1,2,3,4,4a,7,8,8a-octahydro-1,6-dimethyl & 0.4 \\
\hline 29 & 1587 & 1H-Imidazole, 4,5-dihydro-2-(Phenylmethyl) & 1.9 \\
\hline 30 & 1669 & Ethyl homovanillate & 0.4 \\
\hline 31 & 1878 & Hexadecanoic acid, methyl ester & 2.4 \\
\hline 32 & 1908 & 1,2-Benzenedicarboxylic acid, bis(2-methylpropyl) & 0.2 \\
\hline 33 & 2013 & Isopropyl Palmitate & 0.3 \\
\hline 34 & 2013 & 3-Chlorophenyl- $\beta$-phenylpropionate & 0.2 \\
\hline 35 & 2077 & Heptadecanoic acid, ethyl ester & 0.9 \\
\hline 36 & 2077 & Octadecanoic acid, methyl ester & 1.0 \\
\hline
\end{tabular}


Continued

\begin{tabular}{llcl}
\hline 37 & 2085 & $9 \mathrm{E}-$ Octadecenic acid, methyl ester & 1.8 \\
38 & 2093 & $9 \mathrm{Z}, 12 \mathrm{Z}-$ Octadecadienoic acid, methyl ester & 1.9 \\
39 & 2095 & $9-$ Octadecynoic acid, methyl ester & 0.9 \\
40 & 2177 & Octadecanoic acid, ethyl ester & 0.3 \\
41 & 2305 & 1-Bromoeicosane & 0.5 \\
42 & 2722 & 3,6-Bis(4-methylphenyl)-1,2-dihydrotetrarine & 1.9 \\
43 & 2914 & 2E,6E,14E,18E,22E-Tetracosahexaene,2,6,10,15,19,23-hexamethyl & 0.6 \\
44 & 3997 & Tetracontane & 0.4 \\
45 & 5389 & Tetrapentacontane & 0.5 \\
\hline
\end{tabular}

${ }^{a}$ Retention indices obtained on a HP-Innowax column.

The constituent with the highest content in APEO is eucalyptol (8.7\%), followed by $\alpha$-humulene (6.6\%), bornyl acetate (6.3\%), $\beta$-caryophyllene $(5.2 \%)$, bicyclo[3.1.1]hept-2-ene,2,6-dimethyl-6-(4-methyl) (5.2\%), naphthalene, 1,2,3,4,4a,5,6,8a-octahydro-7-methyl (3.8\%), $1 \mathrm{H}$-cycloprop[e]azulene,decahydrop-1,1,7-trimethyl (3.8\%), fenchyl acetate (3.4\%), benzenepropanal (3.4\%), bornyl acetate (3.3\%), benzylacetone (3.3\%), 3-cyclohexene-1-methanol, $\alpha, \alpha, 4$-trimethyl (3.1\%), bicyclo[2.2.1]heptan-2-one (2.9\%), etc. These constituents can be divided into five kinds: sesquiterpene hydrocarbons, benzene hydrocarbons, naphthalenes, lipids and others, where sesquiterpene hydrocarbons account for $44.4 \%$ of APEO.

\subsection{Effect of APEO on Cancer Cell Proliferation in Vitro}

To evaluate the effects of APEO on proliferation of human cancer cell lines, the MTT assay was applied to various cancer cell lines (A549, NCI-H460, NCI-H23, MCF-7, HL-60, and Hela) in vitro. The results showed that APEO significantly inhibited the cell growth and proliferation of these cancer cells in a dose-dependent manner (Figure 1(A)). We also found that human lung cancer cell lines (A549, NCI-H460, and NCI-H23) were more sensitive to APEO than the other three cell lines (Hela, MCF-7, and HL-60). Therefore, in the following studies, A549 cell line was chosen to investigate the anti-cancer effect and associated mechanisms of APEO.

\subsection{Effect of APEO on Tumor Growth in Vivo}

We established A549 xenografts in nude mice in order to evaluate the in vivo anti-cancer effect of APEO. APEO gave a dose-dependent suppression of tumor growth compared to the control $(p<0.05)$, as illustrated in Figure 1(B). However, there was no statistically significant difference between body weights of APEO-treated and glycerin-treated mice ( $p>0.05$, data not shown), suggesting a low general toxicity of APEO. 

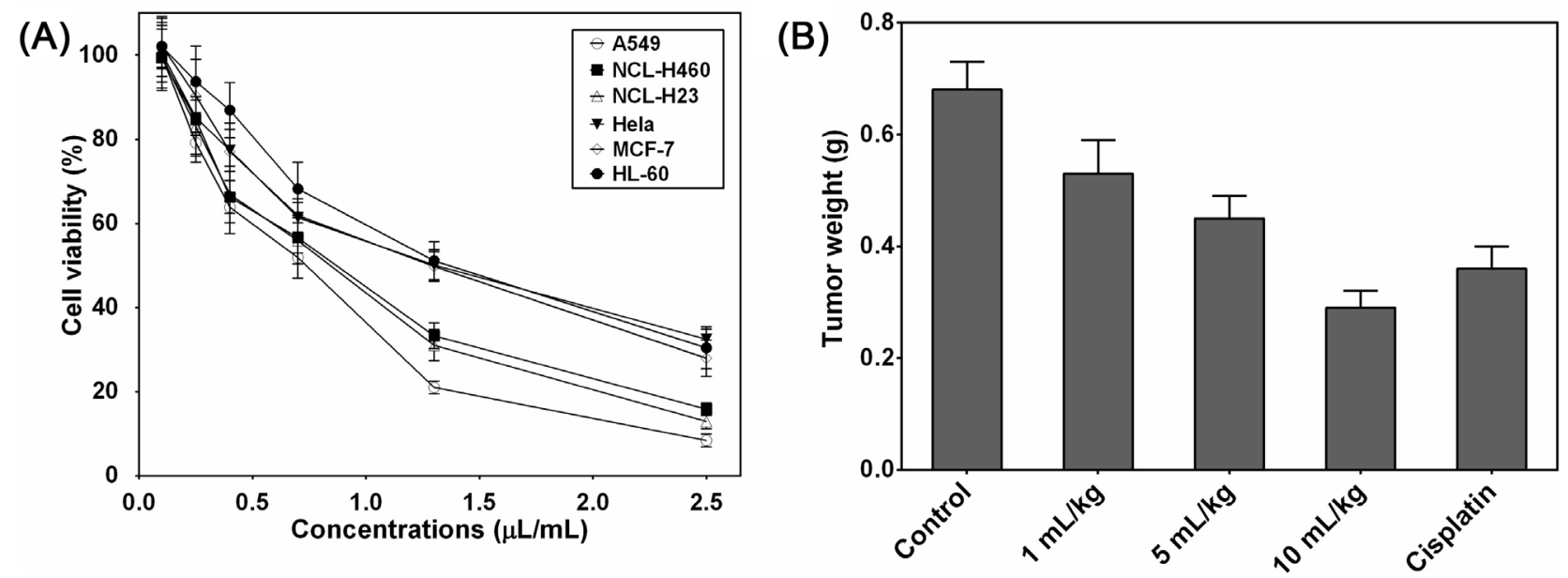

Figure 1. Effects of APEO on the growth of cancer cells. (A) Cell viability of six cancer cell lines determined by the MTT assay after treatments with APEO. The values are represented as the percentage of viable cells compared to control cells. Each point represents as the mean \pm SD from three independent experiments; (B) Volumes of tumors in the mice sacrificed 20 days after the treatments $\left({ }^{\star} p<0.05\right.$ vs control). The values presented are the mean $\pm \mathrm{SD}(\mathrm{n}=10$ in each group).

\subsection{Effect of APEO on Cell-Cycle Distribution}

To further assess whether cell growth inhibition by APEO is associated with cell cycle arrest, the cell-cycle distribution of A549 cells treated with APEO was analyzed using flow cytometry. A S-phase cell cycle arrest was indicated by a significantly increased proportion of cells in S phase after treatment with APEO. As seen in Figure 2(A) and Figure 2(B), 64.846\% of the cells stayed in the S phase when exposed to $0.313 \mu \mathrm{L} / \mathrm{mL}$ of APEO, compared to $24.204 \%$ in the control group. It was also found that cell death, measured as the proportion of cells in sub-G1 phase, consistently increased in response to increasing concentrations of APEO.

\subsection{Apoptosis Induced by APEO}

For assessing cell apoptosis, A549 cells were analyzed by flow cytometry using Annexin V/PI double staining. As shown in Figure 3(A), the proportion of Annexin V-positive cells (total apoptotic cells) significantly increased from $8.11 \%$ in control cells to $22.8 \%, 63.5 \%$, and $79.6 \%$ in $0.078,0.156,0.313 \mu \mathrm{L} / \mathrm{mL}$ APEO-treated cells, which suggests a dose-dependent apoptosis induction. Data from the DAPI staining was consistent with the Annexin V/PI assay. The ratio of cells with apoptotic nuclear morphology (fragmented nuclei and condensed chromatin) to the total cells was markedly increased $24 \mathrm{~h}$ after APEO treatment, compared to the control group (Figure 3(B)).

\subsection{Effect of APEO on $\Delta \Psi \mathrm{m}$}

The maintenance of $\Delta \Psi \mathrm{m}$ is crucial for cell survival and function. Mitochondria undergo major changes in membrane integrity before the classic signs of apoptosis appear, leading to a disruption of the inner $\Delta \Psi \mathrm{m}$ and the release of intermembrane proteins through the outer membrane. The loss of $\Delta \Psi \mathrm{m}$ is a hallmark of apoptosis. In this study, $\Delta \Psi \mathrm{m}$ assays were performed using the $\Delta \Psi \mathrm{m}$-sensitive 

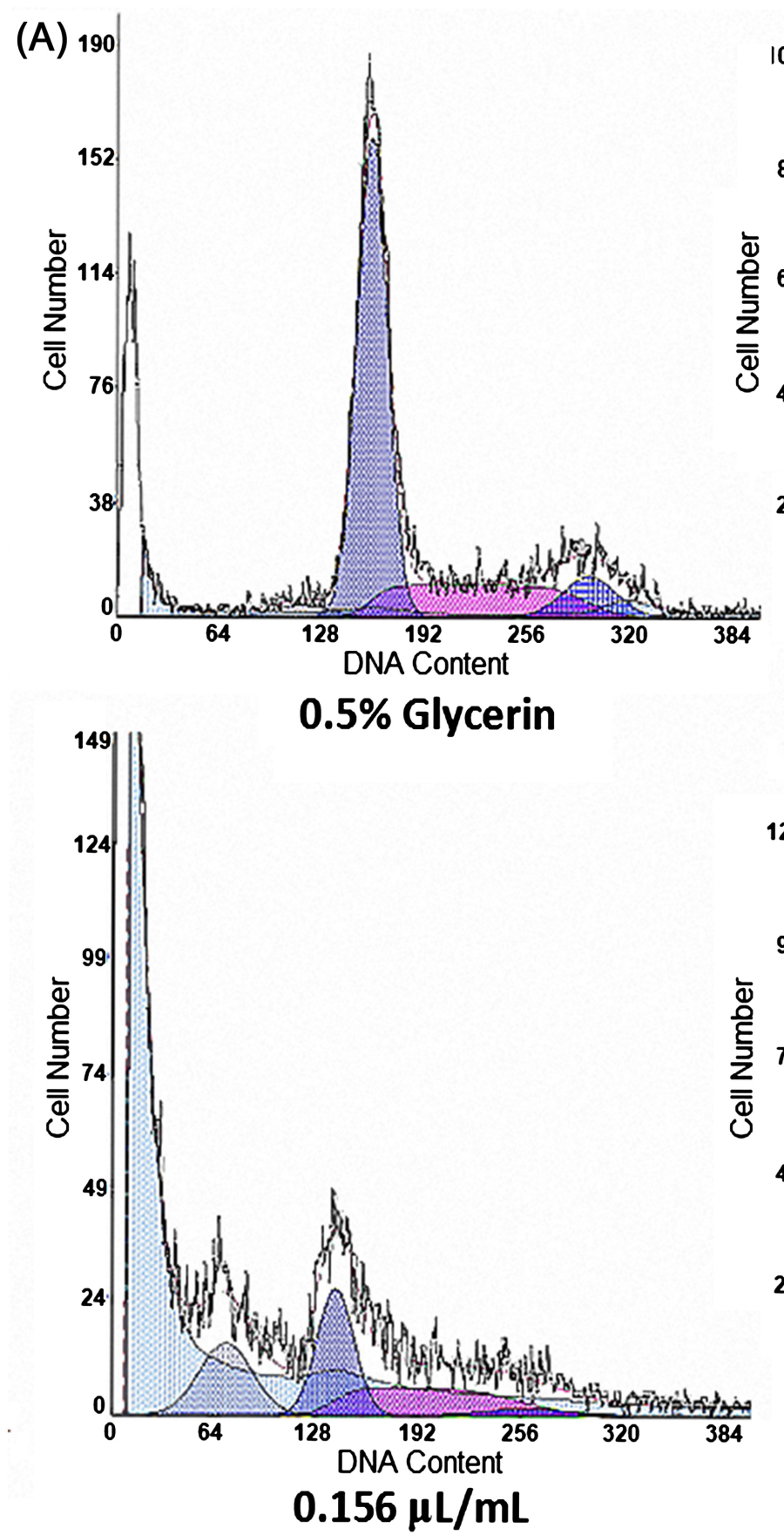

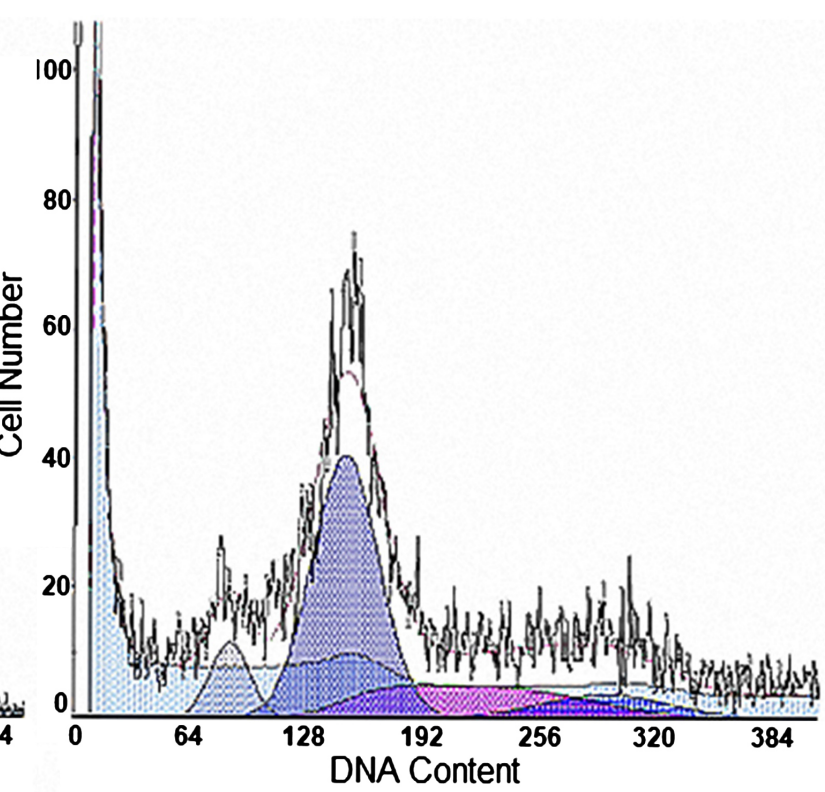

$0.078 \mu \mathrm{L} / \mathrm{mL}$

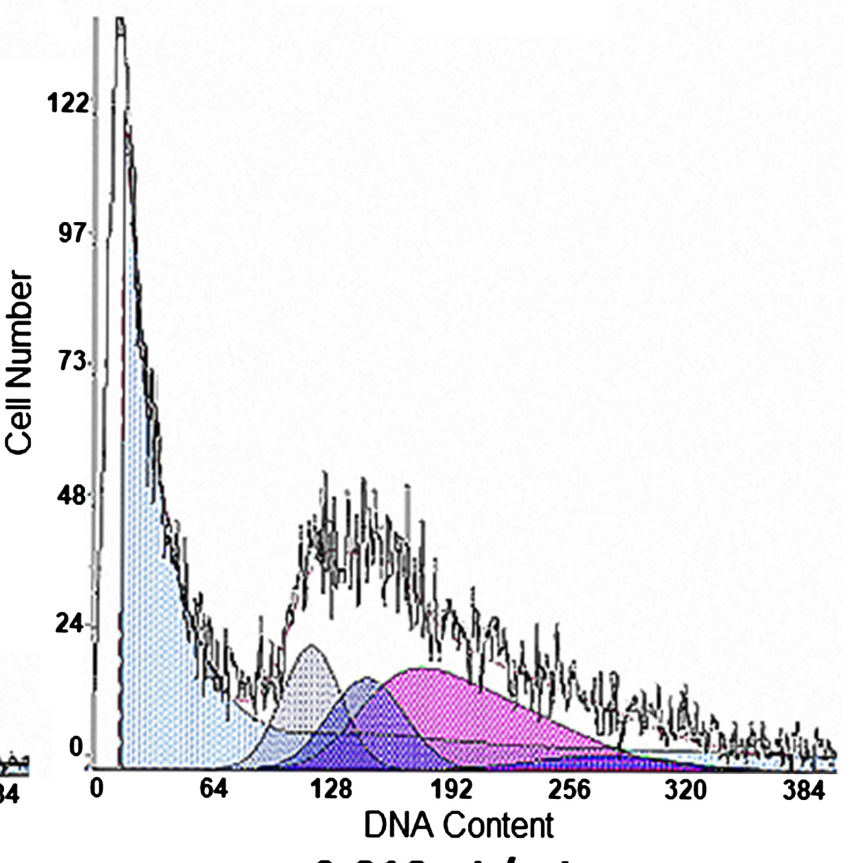

(B)

\begin{tabular}{ccccc}
\hline \multirow{2}{*}{ Cell cycle } & \multicolumn{4}{c}{ Percentage $(\%)$} \\
\cline { 2 - 5 } & $\mathbf{0 . 5 \%}$ Glycerin & $\mathbf{0 . 0 7 8} \boldsymbol{\mu L} / \mathbf{m L}$ & $\mathbf{0 . 1 5 6} \boldsymbol{\mu L} / \mathbf{m L}$ & $\mathbf{0 . 3 1 3} \boldsymbol{\mu L} / \mathbf{m L}$ \\
\hline G0/G1 & 65.971 & 55.965 & 49.231 & 26.901 \\
S & 24.204 & 29.332 & 44.259 & 64.846 \\
G2/M & 9.825 & 13.206 & 6.510 & 8.253 \\
\hline
\end{tabular}

Figure 2. Cell cycle analysis of A549 cells treated with APEO for 24 hours using flow cytometry. (A) Cell-cycle profile examined using flow cytometry with PI staining. Cell numbers were counted based on DNA content of G0/G1, S, and G2/M phases; (B) Statistics for cell numbers of G0/G1, S and G2/M phases of the cell cycle. The data are the mean of three independent experiments. 
fluorescent probe JC-1. The APEO treatment increased the number of cells with collapsed $\Delta \Psi \mathrm{m}$, see B4 in Figure 3(C).

\subsection{APEO Induces Activation of Caspase-3 in A549 Cells}

Caspases are a family of cysteine proteases that play essential roles in regulating apoptosis. Among them, caspase- 3 is a frequently activated death protease, catalyzing the specific cleavage of many key cellular proteins. Caspase- 3 is required for some typical hallmarks of apoptosis, such as apoptotic bodies and chromatin condensation, as well as DNA fragmentation [25]. To determine whether caspase-3 is involved in APEO-induced apoptosis, the protein expression of caspase-3 was examined by Western blot. Data presented in Figure 4(A) and Figure 4(B) indicate a significant increase in the levels of caspase-3 in APEO-treated cells.

\subsection{Effect of APEO on Protein Levels of the Bcl-2 Family}

The Bcl-2 family is most notable for their regulation of apoptosis, consisting of
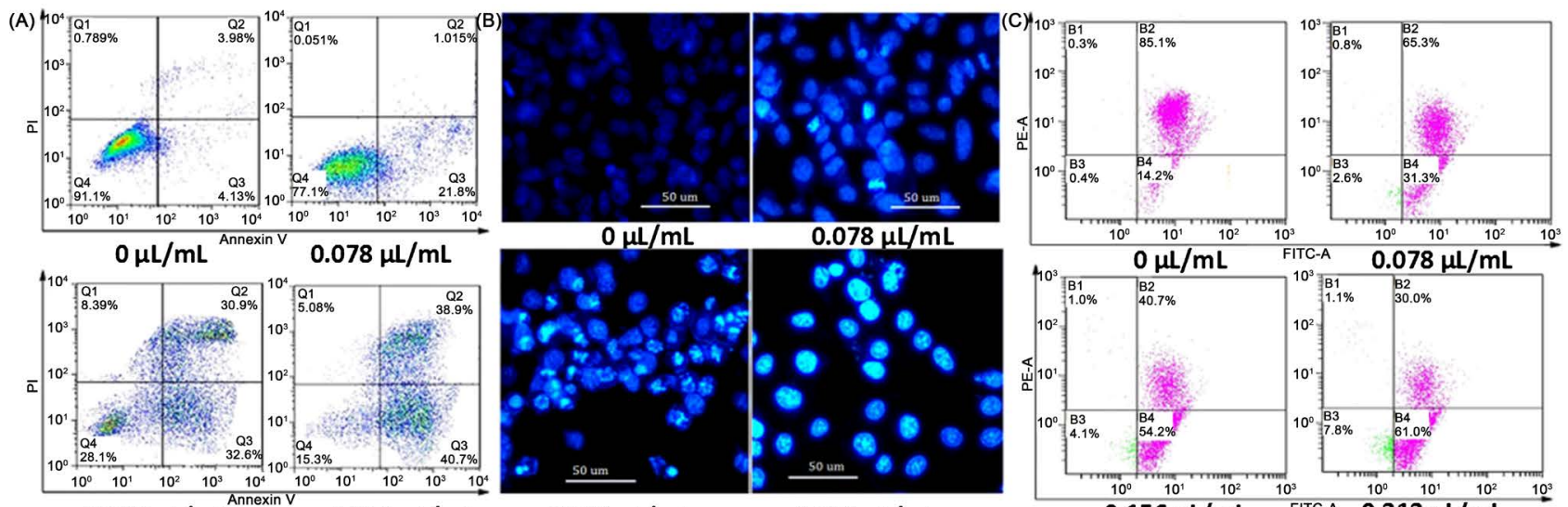

$0.156 \mu \mathrm{L} / \mathrm{mL}$

$0.313 \mu \mathrm{L} / \mathrm{mL}$

$0.156 \mu \mathrm{L} / \mathrm{mL}$

$0.313 \mu \mathrm{L} / \mathrm{mL}$

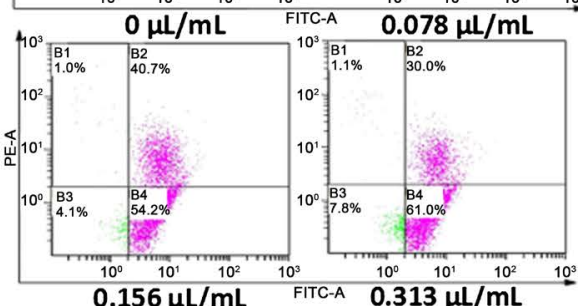

Figure 3. Apoptosis induction by APEO in A549 cells. (A) Apoptosis was analyzed using Annexin V/PI staining after 24 h of treatment with APEO at designed concentrations, and representative histograms are presented here; (B) Nuclear morphology was analyzed using fluorescence microscopy following DAPI staining after $48 \mathrm{~h}$ of treatment with APEO and representative images are shown; (C) $\triangle \Psi \mathrm{m}$ was measured via JC-1 staining after $24 \mathrm{~h}$ of treatment with APEO and representative images are shown. APEO decreased the $\Delta \Psi \mathrm{m}$ of A549 cells. The percentage of the cells with collapsed $\Delta \Psi \mathrm{m}$ is in B4.

(A)

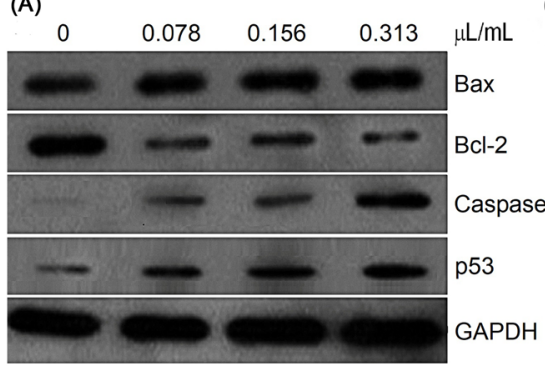

(B)

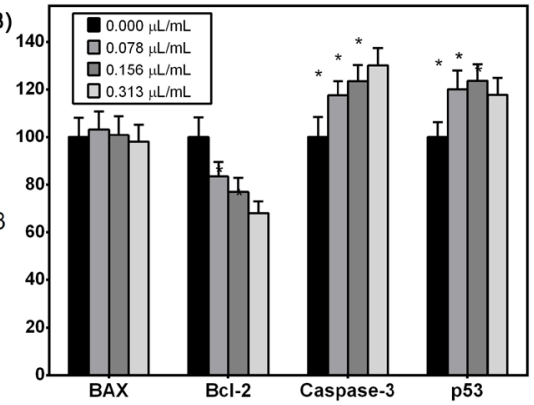

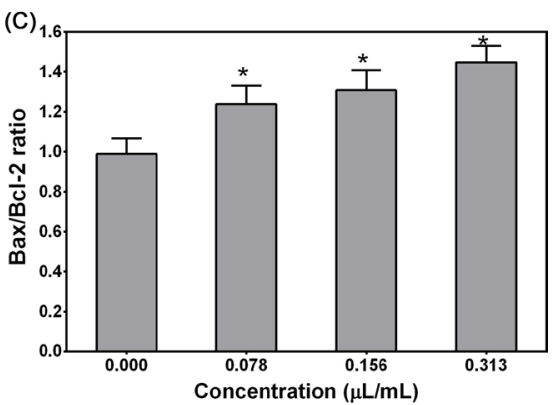

Figure 4. Effects of APEO on protein expression of Bax, Bcl-2, caspase-3 and p53 in A549 cells. (A) The protein levels of Bax, Bcl-2, caspase-3 and p53 measured by Western blot analysis. (B) Quantification of Bax, Bcl-2, caspase-3 and p53 proteins by ImageJ software. (C) Bar diagram representing Bax/Bcl-2 ratio. Three independent experiments were performed, and the data are presented as the mean $\pm \mathrm{SD}\left({ }^{*} p<0.05\right)$. 
members that either promote or inhibit apoptosis. It has been suggested that the ratio of $\mathrm{Bax}$ (an apoptosis promoter) to $\mathrm{Bcl}-2$ (an apoptosis inhibitor) is very important in determining apoptosis. We observed that the APEO treatment of A549 cells resulted in a significant decrease in Bcl-2 expression but had no effect on Bax expression (Figure 4(A) and Figure 4(B)), thus altering the Bax/Bcl-2 ratio in favor of apoptosis (Figure $4(\mathrm{C})$ ).

\subsection{Effect of APEO on Expression of p53 in A549 Cells}

The p53 protein is a transcription factor, which can directly activate a variety of genes important for cell cycle arrest and apoptosis [26]. Thus, we investigated whether p53 participates in APEO-induced apoptosis, using Western blot to quantify the expression of p53. As shown in Figure 4(A) and Figure 4(B), APEO-treated cells had a marked increase in the level of p53 as compared to control cells.

\subsection{Effect of APEO on Proliferation of Rat Osteoblasts in Vitro}

To investigate the effect of APEO on rat osteoblast proliferation, the MTT assay was performed. We found that APEO did not affect the growth of rat osteoblasts at low concentrations $(p>0.05)$, and exerted a slightly negative effect at high concentrations $(p<0.05)$, see Figure $5(\mathrm{~A})$.

\subsection{Effects of APEO on ALP Activity in Rat Osteoblasts}

One trait of a mature osteoblast phenotype is the ability of the cells to synthesize ALP, which is considered an early marker of osteoblast differentiation [27]. To determine whether APEO could stimulate osteogenic differentiation, the ALP activity of cells was determined by a colorimetric assay. Our data indicated that treatment with APEO stimulated ALP activity of rat osteoblasts in a dose-dependent manner (Figure 5(B)). The ALP activity of rat osteoblasts was increased and reached a peak on day 7 after the APEO treatment. In particular, $0.156 \mu \mathrm{L} / \mathrm{mL}$ of the essential promoted the ALP activity of rat osteoblasts by $44 \%$ on day 7 as compared with the control.

\subsection{Effects of APEO on Formation of Mineralized Bone Nodules}

The mineralized bone nodules formed from rat osteoblast cells were observed 20 days after treatment. The mineralized bone nodules could be visualized by the naked eye as red-purple spots after staining with alizarin red (Figure $5(C)$ ). The addition of APEO increased the formation of mineralized nodules by $98.8 \%$, $103.9 \%, 84.8 \%$ and $164.3 \%$ at the concentrations of $0.020,0.039,0.078$ and $0.156 \mu \mathrm{L} / \mathrm{mL}$, respectively, compared with the control (Figure $5(D)$ ).

\section{Discussion}

APEO was obtained from the aerial part of $A$. officinarum, which has been little studied so far. APEO only displays a partial similarity compared to the essential 

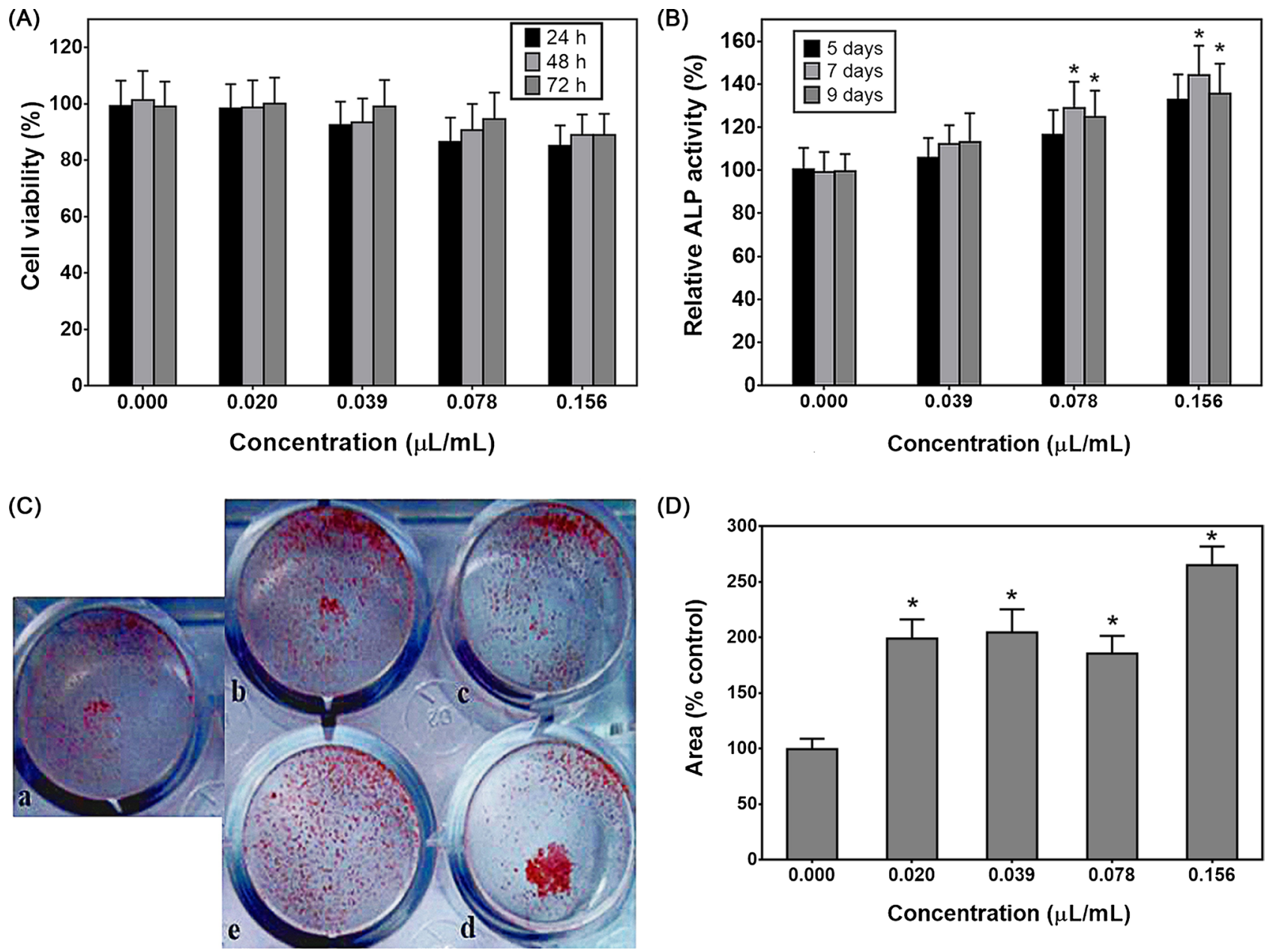

Figure 5. Effects of APEO on proliferation, differentiation, and mineralization of rat osteoblasts. (A) Viability of rat osteoblasts at different time points after treatment with APEO, measured by MTT assay; (B) ALP activity in rat osteoblast cells at different time points after treatment; (C) Formation of mineralized nodules stained with alizarin red after the APEO treatments; (D) Area of mineralized bone nodules stained with alizarin red. Three independent experiments were performed, and the data are presented as the mean $\pm \mathrm{SD}\left({ }^{*} p<0.05\right)$.

oil from the rhizome, with significant differences in the case of certain constituents. Some compounds were not detected in the rhizome, but exists as the major constituents in the aerial part, including naphthalene,

1,2,3,4,4a,5,6,8a-octahydro-7-methyl;

1H-cycloprop[e]azulene,decahydrop-1,1,7-trimethyl;

bicyclo[3.1.1]hept-2-ene,2,6-dimethyl-6-(4-methyl); bornyl acetate; fenchyl acetate; 3-cyclohexene-1-methanol, $\alpha, \alpha, 4$-trimethyl; benzenepropanal and bicyclo[2.2.1] heptan-2-one. Some other compounds are present at largely different concentrations in the rhizome and aerial part of $A$. officinarum, such as eucalyptol ( $8.7 \%$ vs $51.1 \%)$ and benzylacetone (3.3\% vs $0.8 \%)$ [28]. This difference in chemical compositions no doubt excited our interest in further investigating the bioactivities of APEO.

The antiproliferative and proapoptotic activities of APEO against human cancer cells were investigated in this study. Our results have shown that APEO 
are able to effectively inhibit proliferation of various human cancer cells (A549, NCI-H460, NCI-H23, MCF-7, HL-60, and Hela) in dose-dependent manner in vitro. The effects are in good agreement with that observed in A549 xenografts in nude mice. Some sesquiterpenes in APEO have been reported to negatively affect growth and proliferation of cancers in previous literature, such as $\alpha$-humulen [29], $\alpha$-santalol [30], $\beta$-caryophyllene and $\beta$-caryophyllene oxide [31]. The antiproliferative activity of APEO might be concerned with abundant sesquiterpenes in APEO. In addition, APEO significantly induced S-phase arrest in the cell cycle progression. Thus, suppression of cell proliferation by APEO involves a cell cycle arrest during $S$ phase in cancer cells.

The treatment with APEO induced a dose-dependent apoptosis in A549. The related mechanisms were investigated in this study. Bcl-2 family proteins together regulate and control the process by which mitochondria contribute to cell death known as the intrinsic apoptosis pathway. Bcl-2 is an upstream effector molecule in the apoptotic pathway, and has been identified as a potent suppressor of apoptosis [32]. Bcl-2 forms a heterodimeric complex with the proapoptotic protein Bax, thereby neutralizing their apoptotic effects. Thus, the ratio of $\mathrm{Bax} / \mathrm{Bcl}-2$ is considered to be a crucial factor in determining whether cell die or survive [33]. Our study showed that, APEO significantly downregulated Bcl-2 protein and consequently upregulated $\mathrm{Bax} / \mathrm{Bcl}-2$ ratio. Therefore, downregulation of Bcl-2 may be a molecular mechanism of APEO to induce apoptosis of cancer cells.

The intrinsic mitochondria-mediated pathway in apoptotic death mainly involves the mitochondrial permeability transition (MPT) due to the opening of the permeability transition pores at the mitochondrial membrane, followed by the loss in $\Delta \Psi \mathrm{m}$ and the release of intermembrane space protein, cytochrome c [34]. Released cytochrome $c$ activates Apaf-1, which in turn activates downstream caspases (e.g., caspase- 9 and caspase-3). This pathway is regulated by interplay between members of $\mathrm{Bcl}-2$ protein family, with the ratio of $\mathrm{Bax} / \mathrm{Bcl}-2$ considered as a major checkpoint in the pathway [35]. Thus, as might be expected from the change of $\mathrm{Bax} / \mathrm{Bcl}-2$ ratio, $\Delta \Psi \mathrm{m}$ was observed to have a significant decrease in A549 cells treated with APEO. Also, the expression of caspase-3 was upregulated. These results suggest the involvement of an intrinsic apoptotic pathway in apoptotic induction of APEO against cancer cells.

Tumor protein $\mathrm{p} 53$ is crucial in multicellular organisms, where it functions as a tumor suppressor. The pathway through which p53 promotes apoptosis involves transcriptional regulation of target genes as well as non-transcriptional activities of p53 within mitochondria-mediated cell death pathways that are based on p53 protein accumulation in cytosolic and mitochondrial compartments and protein-protein interaction [36]. In this study, APEO significantly increased the expression of p53 in A549 cells. This may explain our observation that the expression of Bcl-2 was potently reduced in APEO treated A549 cells, since p53 can act to repress Bcl-2 transcription. Although the p53-mediated 
transactivation of Bax has been widely reported, the cells exhibited no significant change in the level of Bax after the APEO treatment, probably due to distinct mechanisms of p53 in different cellular contexts [37]. To sum up these findings presented above, APEO could induce apoptosis through downregulating Bcl-2 expression and subsequently increasing the Bax/Bcl-2 ratio via p53 signal pathway in cancer cells. A similar observation that dihydromyricetin reduced Bcl-2 expression via p53 to induce apoptosis in HepG2 cells has been reported by $\mathrm{Wu}$ et al. [38]. Above all, the ability of APEO to inhibit cell proliferation and induce apoptosis suggests that it might be an ideal therapeutic agent for lung cancer.

Meanwhile, patients with cancer are at risk for many adverse skeletal effects, including metastatic bone disease and treatment-related bone loss. Many solid tumors are associated with metastatic skeletal effects; patients with cancer who suffer fractures could experience decreased chances of survival [39]. Patients with prostate cancer who have sustained a fracture have a lower survival rate compared to patients without a fracture [40]. Tumor cells that metastasize to bone produce local factors that enhance their engraftment into bone and interact with local bone cells to promote an environment for their survival via local bone destruction and the formation and recruitment of an adequate vascular supply. Osteoporosis is a disease characterized by loss of bone mass and degeneration of bone microstructure, increasing the risk of a broken bone. The maintenance of normal bone requires the removal of old or damaged bone by osteoclasts (bone resorption) and the subsequent replacement of new bone formed by osteoblasts (bone formation) [41]. During bone formation, osteoblasts would go through three development phases: proliferation, osteogenic differentiation and mineralization of the extracellular matrix [42]. The phenotype of mature osteoblasts is characterized by their ability to synthesize and secrete molecules of the extracellular matrix, as well as production of ALP [43]. ALP promotes mineralization of the extracellular matrix by hydrolyzing phosphate esters, thereby increasing the local phosphate concentration [44]. ALP has been identified as an early marker of osteoblast differentiation [27]. Our findings that APEO stimulated ALP activity of rat osteoblasts and increased the formation of mineralized nodules, suggest that APEO activates the osteogenic differentiation of rat osteoblasts and enhance mineralization of the extracellular matrix. However, in higher concentrations, APEO can inhibit the growth and proliferation of rat osteoblasts, although the effect appears to be very weak. More work has to be meticulously done to figure out the effective but harmless doses of APEO for treatment of osteoporosis.

\section{Conclusion}

In conclusion, the essential oil from the aerial part of $A$. officinarum contains five classes of components: sesquiterpene hydrocarbons, benzene hydrocarbons, naphthalenes, lipids and others. And sesquiterpene hydrocarbons account for $44.4 \%$ of APEO. The essential oil could effectively inhibit tumor growth in vitro and in vivo; Its high anticancer activity might derive from the high amount of 
sesquiterpenes the oil contains. Our results indicate that the apoptosis of A-549 cells induced by APEO might involve apoptosis-regulated proteins (p53, caspase-3, Bax, Bcl-2). Therefore, consumption of APEO could be an effective strategy for cancer protection. In addition, our findings showed that APEO promoted osteogenic differentiation and mineralization simultaneously in rat osteoblastic cells, indicating the benefit of using the essential oil to promote bone health, especially for cases of osteoporosis caused by cancer.

\section{Authors' Contributions}

XBZ and JT developed the concept of this study. YW, JC, KDZ, WGW, LLG, HQW, and JML designed and performed experiments and analysed data. XBZ, and JT prepared the draft and final version of the manuscript. All authors read and approved the final manuscript.

\section{Acknowledgements}

This work was supported by grants from the National Natural Science Foundation of China (81503221, 81703939), the Guangdong Natural Science Fund (2017A030313659, 2014A030310365), Shenzhen Technical Development Project (CXZZ20150402104158173) and Shenzhen Basic Research Project (JCYJ20170307095556333, JCYJ20170413093108233, JCYJ20160427183814675).

\section{Competing Interests}

The authors declare that they have no conflict of interest.

\section{Availability of Data and Materials}

The datasets used and/or analyzed during the current study are available from the corresponding author on reasonable request.

\section{Consent for Publication}

All of authors consent to publication of this study in Journal of Chinese Medicine.

\section{Ethics Approval and Consent to Participate}

Animal protocol was conducted according to the animal procedure approved by Institutional Animal Care and Use Committee of the Shenzhen People's Hospital (Approval Document No. LL-KT-201701017).

\section{References}

[1] Jiang, Z., Akhtar, Y., Bradbury, R., Zhang, X. and Isman, M.B. (2009) Comparative Toxicity of Essential Oils of Litsea pungens and Litsea cubeba and Blends of Their Major Constituents against the Cabbage Looper, Trichoplusia ni. Journal of Agricultural and Food Chemistry, 57, 4833-4837. https://doi.org/10.1021/jf900274r

[2] Bakkali, F., Averbeck, S., Averbeck, D. and Idaomar, M. (2008) Biological Effects of 
Essential Oils-A Review. Food and Chemical Toxicology, 46, 446-475. https://doi.org/10.1016/j.fct.2007.09.106

[3] Lim, T.K. (2016) Edible Medicinal and Non-Medicinal Plants: Modified Stems, Roots, Bulbs. Vol. 12, Springer, Berlin.

[4] Matsuda, H., Nakashima, S., Oda, Y., Nakamura, S. and Yoshikawa, M. (2009) Melanogenesis Inhibitors from the Rhizomes of Alpinia officinarum in B16 Melanoma Cells. Bioorganic \& Medicinal Chemistry, 17, 6048-6053. https://doi.org/10.1016/j.bmc.2009.06.057

[5] Srividya, A.R., Dhanabal, S.P., Misra, V.K. and Suja, G. (2010) Antioxidant and Antimicrobial Activity of Alpinia officinarum. Indian Journal of Pharmaceutical Sciences, 72, 145-148. https://doi.org/10.4103/0250-474X.62233

[6] Lin, L.Y., Shen, K.H., Yeh, X.Y., Huang, B.Y., Wang, H.E., Chen, K.C., et al. (2016) Integrated Process for Production of Galangal Acetate, the "Wasabi-Like" Spicy Compound, and Analysis of Essential Oils of Rhizoma Alpinia officinarum (Hance) Farw. Journal of Food Science, 81, H1565-1575.

https://doi.org/10.1111/1750-3841.13326

[7] Luo, H., Cai, C. and Liu, J.Q. (1998) Study on Chemical Components of Essential Oil from Fresh Rhizome of Alpinia officinarum Hance. Chinese Journal of Modern Applied Pharmacy, 1, 6.

[8] Fischer, J. and Dethlefsen, U. (2013) Efficacy of Cineole in Patients Suffering from Acute Bronchitis: A Placebo-Controlled Double-Blind Trial. Cough, 9, 25.

https://doi.org/10.1186/1745-9974-9-25

[9] Murata, S., Shiragami, R., Kosugi, C., Tezuka, T., Yamazaki, M., Hirano, A., et al. (2013) Antitumor Effect of 1,8-Cineole against Colon Cancer. Oncology Reports, 30, 2647-2652. https://doi.org/10.3892/or.2013.2763

[10] Vuuren, S.F.V. and Viljoen, A.M. (2007) Antimicrobial Activity of Limonene Enantiomers and 1,8-Cineole Alone and in Combination. Flavour and Fragrance Journal, 22, 540-544. https://doi.org/10.1002/ffj.1843

[11] Guo, X., Shang, X., Li, B., Zhou, X.Z., Wen, H. and Zhang, J. (2017) Acaricidal Activities of the Essential Oil from Rhododendron nivale Hook. f. and Its Main Compound, $\delta$-Cadinene against Psoroptes cuniculi. Veterinary Parasitology, 236, 51-54. https://doi.org/10.1016/j.vetpar.2017.01.028

[12] Govindarajan, M., Rajeswary, M. and Benelli, G. (2016) $\delta$-Cadinene, Calarene and $\delta$-4-Carene from Kadsura heteroclita Essential Oil as Novel Larvicides against Malaria, Dengue and Filariasis Mosquitoes. Combinatorial Chemistry \& High Throughput Screening, 19, 565-571. https://doi.org/10.2174/1386207319666160506123520

[13] Hui, L.M., Zhao, G.D. and Zhao, J.J. (2015) $\delta$-Cadinene Inhibits the Growth of Ovarian Cancer Cells via Caspase-Dependent Apoptosis and Cell Cycle Arrest. International Journal of Clinical and Experimental Pathology, 8, 6046-6056.

[14] Zhang, H., Xu, L., Wu, P. and Wei, X. (2014) Flavonoids from the Aerial Parts of Alpinia officinarum. Journal of Tropical and Subtropical Botany, 22, 89-92.

[15] Zhang, J.Q., Wang, Y., Li, H.L., Wen, Q., Yin, H., Zeng, N.K., et al. (2015) Simultaneous Quantification of Seventeen Bioactive Components in Rhizome and Aerial Parts of Alpinia officinarum Hance Using LC-MS/MS. Analytical Methods, 7, 4919-4926. https://doi.org/10.1039/C5AY00647C

[16] Ferlay, J., Shin, H.R., Bray, F., Forman, D., Mathers, C. and Parkin, D.M. (2010) Estimates of Worldwide Burden of Cancer in 2008: GLOBOCAN 2008. International Journal of Cancer, 127, 2893-2917. https://doi.org/10.1002/ijc.25516

[17] He, X.J., Wang, Y.H., Hu, H. and Zhang, Z.X. (2012) In Vitro and in Vivo Anti- 
mammary Tumor Activities and Mechanisms of the Apple Total Triterpenoids. Journal of Agricultural and Food Chemistry, 60, 9430-9436. https://doi.org/10.1021/jf3026925

[18] Mancini, M., Anderson, B.O., Caldwell, E., Sedghinasab, M., Paty, P.B. and Hockenbery, D.M. (1997) Mitochondrial Proliferation and Paradoxical Membrane Depolarization during Terminal Differentiation and Apoptosis in a Human Colon Carcinoma Cell Line. Journal of Cell Biology, 138, 449-469. https://doi.org/10.1083/jcb.138.2.449

[19] Eastman, A. (1993) Apoptosis: A Product of Programmed and Unprogrammed Cell Death. Toxicology and Applied Pharmacology, 121, 160-164. https://doi.org/10.1006/taap.1993.1141

[20] Brown, S.A. and Guise, T.A. (2007) Cancer-Associated Bone Disease. Current Osteoporosis Reports, 5, 120-127. https://doi.org/10.1007/s11914-007-0027-8

[21] Rizzoli, R., Body, J.J., Brandi, M.L., Cannata-Andia, J., Chappard, D., EI Maghraoui, A., et al. (2013) Cancer-Associated Bone Disease. Osteoporosis Internatural, 24, 2929-2953. https://doi.org/10.1007/s00198-013-2530-3

[22] Adams, R.P. (2001) Identification of Essential Oils Components by Gas Chromatography/Mass Spectroscopy. Allured Publishing Corporation, Carol Stream.

[23] Bradford, M.M. (1976) A Rapid and Sensitive Method for the Quantitation of Microgram Quantities of Protein Utilizing the Principle of Protein-Dye Binding. Analytical Biochemistry, 72, 248-254. https://doi.org/10.1016/0003-2697(76)90527-3

[24] Declercq, H., Van den Vreken, N., De Maeyer, E., Verbeeck, R., Schacht, E., De Ridder, L., et al. (2004) Isolation, Proliferation and Differentiation of Osteoblastic Cells to Study Cell/Biomaterial Interactions: Comparison of Different Isolation Techniques and Source. Biomater, 25, 757-768. https://doi.org/10.1016/S0142-9612(03)00580-5

[25] Porter, A.G. and Janicke, R.U. (1999) Emerging Roles of Caspase-3 in Apoptosis. Cell Death and Differentiation, 6, 99-104. https://doi.org/10.1038/sj.cdd.4400476

[26] Pietsch, E.C., Sykes, S.M., McMahon, S.B. and Murphy, M.E. (2008) The p53 Family and Programmed Cell Death. Oncogene, 27, 6507-6521. https://doi.org/10.1038/onc.2008.315

[27] Yoshiko, Y., Maeda, N. and Aubin, J.E. (2003) Stanniocalcin 1 Stimulates Osteoblast Differentiation in Rat Calvaria Cell Cultures. Endocrinology, 144, 4134-4143. https://doi.org/10.1210/en.2003-0130

[28] Luo, H., Cai, C., Zhang, J. and Mo, L. (1998) Comparison of the Chemical Components of Essential Oils Alpinia officinarun Hance in Different Locaties. Shizhen Journal of Traditional Chinese Medicine Research, 9, 29-30.

[29] El Hadri, A., del Rio, M.G., Sanz, J., Coloma, A.G., Idaomar, M., Ozonas, B., et al. (2010) Cytotoxic Activity of $\alpha$-Humulene and Transcaryophyllene from Salvia officinalis in Animal and Human Tumor Cells. Anales de la Real Academia Nacional de Farmacia, 76, 343-356.

[30] Saraswati, S., Kumar, S. and Alhaider, A.A. (2013) $\alpha$-Santalol Inhibits the Angiogenesis and Growth of Human Prostate Tumor Growth by Targeting Vascular Endothelial Growth Factor Receptor 2-Mediated AKT/mTOR/P70S6K Signaling Pathway. Molecular Cancer, 12, 147. https://doi.org/10.1186/1476-4598-12-147

[31] Fidyt, K., Fiedorowicz, A., Strzadala, L. and Szumny, A. (2016) $\beta$-Caryophyllene and $\beta$-Caryophyllene Oxide-Natural Compounds of Anticancer and Analgesic Properties. Cancer Medicine, 5, 3007-3017. https://doi.org/10.1002/cam4.816

[32] Vander Heiden, M.G. and Thompson, C.B. (1999) Bcl-2 Proteins: Regulators of 
Apoptosis or of Mitochondrial Homeostasis? Nature Cell Biology, 1, E209-E216. https://doi.org/10.1038/70237

[33] Kroemer, G. and Reed, J.C. (2000) Mitochondrial Control of Cell Death. Nature Medicine, 6, 513-519. https://doi.org/10.1038/74994

[34] Indran, I.R., Tufo, G., Pervaiz, S. and Brenner, C. (2011) Recent Advances in Apoptosis, Mitochondria and Drug Resistance in Cancer Cells. Biochimica et Biophysica Acta, 1807, 735-745. https://doi.org/10.1016/j.bbabio.2011.03.010

[35] Gross, A., McDonnell, J.M. and Korsmeyer, S.J. (1999) BCL-2 Family Members and the Mitochondria in Apoptosis. Genes \& Development, 13, 1899-1911. https://doi.org/10.1101/gad.13.15.1899

[36] Marchenko, N.D. and Moll, U.M. (2014) Mitochondrial Death Functions of p53. Molecular and Cellular Oncology, 1, e955995. https://doi.org/10.1080/23723548.2014.955995

[37] Hemann, M.T. and Lowe, S.W. (2006) The p53-Bcl-2 Connection. Cell Death \& Differentiation, 13, 1256-1259. https://doi.org/10.1038/sj.cdd.4401962

[38] Wu, S., Liu, B., Zhang, Q., Liu, J., Zhou, W., Wang, C., et al. (2013) Dihydromyricetin Reduced Bcl-2 Expression via p53 in Human Hepatoma HepG2 Cells. PLoS ONE, 8, e76886. https://doi.org/10.1371/journal.pone.0076886

[39] Kanis, J.A., Oden, A., Johnell, O., Delaet, C., Jonsson, B., et al. (2003) The Components of Excess Mortality after Hip Fracture. Bone, 32, 468-473.

https://doi.org/10.1016/S8756-3282(03)00061-9

[40] Oefelein, M.G., Ricchiuti, V., Conrad, W. and Resnick, M.I. (2002) Skeletal Fractures Negatively Correlate with Overall Survival in Men with Prostate Cancer. The Journal of Urology, 168, 1005-1007. https://doi.org/10.1016/S0022-5347(05)64561-2

[41] Feng, X. and McDonald, J.M. (2011) Disorders of Bone Remodeling. Annual Review of Phytopathology, 6, 121-145.

https://doi.org/10.1146/annurev-pathol-011110-130203

[42] Raouf, A. and Seth, A. (2000) Ets Transcription Factors and Targets in Osteogenesis. Oncogene, 19, 6455-6463. https://doi.org/10.1038/sj.onc.1204037

[43] Zeng, X., Tian, J., Cai, K., Wu, X., Wang, Y., Zheng, Y., et al. (2014) Promoting Osteoblast Differentiation by the Flavanes from Huangshan Maofeng Tea Is Linked to a Reduction of Oxidative Stress. Phytomedicine, 21, 217-224. https://doi.org/10.1016/j.phymed.2013.08.026

[44] Golub, E.E. and Boesze-Battaglia, K. (2007) The Role of Alkaline Phosphatase in Mineralization. Current Orthopaedic Practice, 18, 444-448. https://doi.org/10.1097/BCO.0b013e3282630851 


\section{Graphical Abstract}

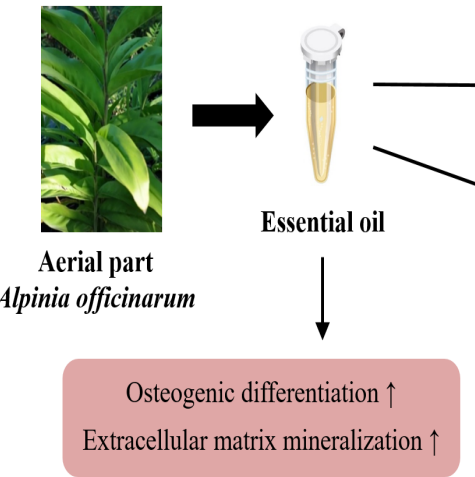

Rat osteoblasts

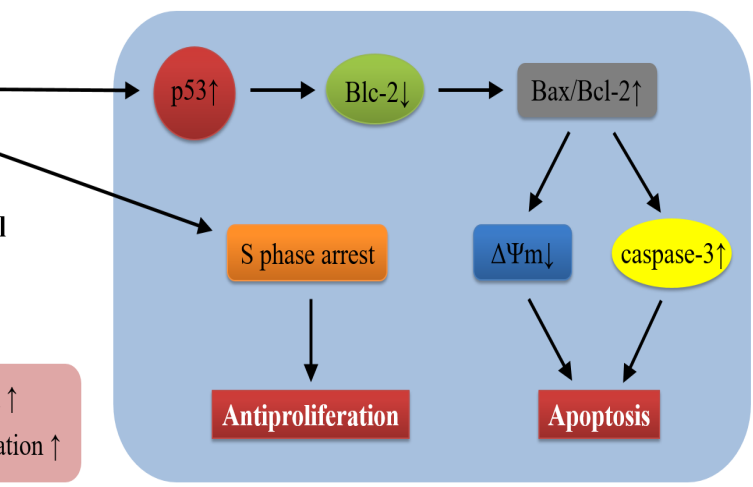

Cancer cells

\section{Abbreviations}

APEO, Essential Oil from the Aerial Parts of Alpinia officinarum

GC-MS, Gas Chromatography-Mass Spectrometry

GC-FID, Gas Chromatography-Flame Ionization Detection

EI, Electron-Impact

$\Delta \Psi \mathrm{m}$, Mitochondrial Membrane Potential

PI, Propidium Iodide

JC-1, 5',6,6'-tetrachloro-1,1',3,3'-tetraethylbenzimidazolylcarbocyanine iodide FBS, Fetal Bovine Serum

MTT, 3-(4,5-Dimethylthiazol-2-yl)-2,5-Diphenyltetrazolium Bromide

$\mathrm{SD}$, Standard Deviation

MPT, Mitochondrial Permeability Transition

ALP, Alkaline Phosphatase 